Article

\title{
Moving Toward a Sustainable Energy System: A Case Study of Viken County of Norway
}

\author{
Fredrik Ege Abrahamsen ${ }^{1, *}$ (D) Sturla Grina Ruud ${ }^{2}$ and Alemayehu Gebremedhin ${ }^{2}$ \\ 1 Department of Electronic Systems, Faculty of Information Technology and Electrical Engineering, \\ NTNU-Norwegian University of Science and Technology, 2815 Gjøvik, Norway \\ 2 Department of Manufacturing and Civil Engineering, Faculty of Engineering, \\ NTNU-Norwegian University of Science and Technology, 2815 Gjøvik, Norway; \\ sturlaru@stud.ntnu.no (S.G.R.); alemayehu.gebremedhin@ntnu.no (A.G.) \\ * Correspondence: fredrik.e.abrahamsen@ntnu.no
}

Received: 16 October 2020; Accepted: 9 November 2020; Published: 12 November 2020

\begin{abstract}
Increasing awareness of climate issues and environmental policy has been a key factor behind the continuous transition of energy systems at different levels. This paper aimed to analyse the energy system of Viken county, located in Norway. An energy system model using the energy system analysis tool EnergyPLAN was developed. Based on the reference year 2018, two future scenarios which focus on changes in the transport sector for the year 2030 and 2050 were designed. Besides changes in the transport sector, the integration of renewable energy sources is considered in the future scenarios. The results of the analysis regarding the future scenario shows substantial $\mathrm{CO}_{2}$ reduction as a result of energy-carrier switching within the transport sector. The integration of new energy sources, in this case, solar PV and wind power, helps to offset increased import dependency. The primary energy supply decrease and the share of renewable energy increases significantly.
\end{abstract}

Keywords: sustainable energy system; energy system analysis; primary energy consumption; transport; electrification; $\mathrm{CO}_{2}$ emission

\section{Introduction}

The integration of clean and affordable energy is one of the most important sustainable development goals. The Paris Climate Agreement and the Sustainable Development Goals (SDGs) define aspirational targets for transitioning to sustainable energy systems and combating climate change and global warming. At the United Nations Climate Change Conference (COP 21) held in Paris, France in December 2015, 196 countries agreed on adopting the Paris Agreement. The Paris Agreement emphasises the urgency and sets out a global framework to limit the rise in global average temperature well below 2 degrees Celsius above preindustrial levels, and limit the temperature increase to 1.5 degrees Celsius to reduce risk and impacts of climate change [1]. The 2030 Climate and Energy Framework sets targets and objectives for the period 2021 to 2030. According to them, greenhouse gasses (GHG) must be reduced by at least 40\% (from 1990 levels), the share of renewable energy increased by $32 \%$ and energy efficiency improved by 32.5\% [2]. To achieve climate neutrality by 2050 the European Commission has established the Green Deal and proposed the Climate Law. The Green Deal is a road map to more efficient use of resources by moving to a circular economy, reducing pollution, becoming climate neutral and decarbonising the energy sector [3]. The Climate Law is a legal binding target of net zero GHG emissions by 2050 [4]. As of February 2020, as part of fulfilling these goals from the Paris Agreement, the Norwegian government has set itself an ambitious target of decreasing GHG emissions by at least 50\%, and towards 55\% compared to 1990 levels by 2030 and $90-95 \%$ by the year 2050 [5-7]. 
The primary energy supply in Norway is based on various renewable energy sources, coal, oil, gas and non-renewable waste. In 2018 Norway produced 2394 TWh energy, oil and gas having the largest share with over $90 \%$ [8]. Norway is a net exporter of electric energy and its domestic power system is already largely based on renewable energy sources. In an average year, around $98 \%$ of the Norwegian electricity production comes from renewable energy sources [9]. In 2018 Norway produced 147 TWh electricity, of which 143.6 TWh was from renewable energy sources. The distribution of electricity generation was: hydroelectric plants $139.5 \mathrm{TWh}$, wind power $3.9 \mathrm{TWh}$ and 0.2 TWh biofuels [9]. After industry and oil and gas sectors, the transport sector is the largest contributor to GHG emissions in Norway. In total $20 \%$ of the total emission in 2018 originate from road traffic [10]. Due to population growth it is expected that $\mathrm{CO}_{2}$ emissions will increase as a result of increased population and transport demand, unless proper actions are taken. To mitigate emissions the Norwegian government has set a number of ambitious goals [11];

- $\quad$ All new passenger vehicles and vans sold after 2025 should be zero-emission.

- All new city buses should be zero-emission or use biogas by 2025 .

- All new heavy vans, $75 \%$ of long-range buses and $50 \%$ of new lorries should be zero-emission by 2030 .

- Goods distribution in major city areas should be zero-emission by 2030.

In Norway the largest consumer of energy is the industrial sector, followed by transport, residential, commercial and public services and agriculture [12]. The national goals for Norway can be compared to Viken; however, Viken county has not released any new goals after the merger of the previous counties Akershus, Østfold and Buskerud and Lunner, Svelvik and Jevnaker municipalities in January 2020. All existing plans regarding climate and environment are the same before the merger. On the other hand, Akershus, Buskerud and Oslo have had common regional climate policies since 1999. These policies mainly focus on increasing renewable energy, reducing emissions and transport [13]. Energy system analysis is a valuable tool to achieve a holistic overview to better understand the different aspects and structures of the energy system as a whole. This information can potentially be used to reach the climate goals set forth in the Paris Agreement. There are some studies related to energy system analysis on national level. The Danish energy system with a target of $100 \%$ renewable energy was analysed in [14]. The potential of reduced $\mathrm{CO}_{2}$ emissions by increasing renewable energy production in Sweden is studied in [15]. Achieving a sustainable energy system through the introduction of renewable energy sources (RES) in the primary energy supply and the considerations of a carbon capturing and storage (CCS) scheme are studied in [16]. A 100\% increase RES for production of electricity, heat and biofuels in Macedonia in 2030 and 2050 was studied in [17]. Integrating of RES such as wind power and CCS to achieve a $100 \%$ renewable energy system by 2050 was studied for Scotland [18]. The authors in [19] studied the development of decarbonisation strategies in China for electricity, transport, heating and industry in 2050. Another study which focused on the regional energy system of Chongming county of China was performed by the authors in [20]. The authors mainly focused on reduction of primary energy supply, emissions and power import. The authors in [21] reviewed the effect of $\mathrm{CO}_{2}$ emissions and excess electricity production in western Denmark; they considered how electric and biofuelled vehicles impact the energy system with high share of fluctuating renewable sources. The same author investigated how vehicle to grid technology affects two different systems, one being a high fluctuating energy system, and another being a non-fluctuating system [22].

The purposes of this study were to conduct a thorough review of Viken county's energy system and climate goals, and to investigate the effects of the proposed actions by establishing scenarios for the years 2030 and 2050. However, the main focus in this study is reducing emissions from the transport sector. Moreover, the world has shown political decisiveness toward reducing GHG emissions nationally, regionally and locally by signing the Paris Agreement. There is not a universal plan for reaching the goals in the Paris Agreement, yet some countries are showing some effort along 
those lines. For instance, Norway, has reached the highest percentage of EVs in the world as a result of significant measures at different levels, thereby reducing the emissions from road traffic.

This study is unique, as it develops an energy system model for a newly established county with respect to electricity demand and transport. This study attempts to give new insights for policy makers regarding future energy and climate strategies. The paper is organised into eight sections: Section 1 provides an introduction presenting relevant background information about reasons for conducting this study. Section 2 describes the methodology, the modelling tool used to perform the analysis, the main objectives, the data sources and the assumptions. Section 3 presents the regional climate and energy strategy and the various goals set for the years 2030 and 2050 by Viken. Section 4 presents Viken's current energy system. Section 5 deals with validation of the baseline model. Section 6 deals with the scenario descriptions. Section 7 will be an overview over the presented results from the simulation. Finally, Section 8 discusses important data from the results, and Section 9 provides conclusions to the paper. Future work arising from the study is addressed in Section 10.

\section{Methodology and Data}

In this section, the research methodology, tools and the inputs used are described. First, an overview of the analysis tool is given, followed by an overview of the main data sources used and assumptions made in order to define the baseline. The following section describes the scenario development for the analysis of 2030 and 2050. The paper addresses the energy system of Viken of today, and in 2030 and 2050 with regards to regional goals. The main focus is energy system analysis with a specific focus on the electrification of the transport sector.

\subsection{The Energy Analysis Tool}

In order to investigate the impacts of the climate and energy goals defined for 2030 and 2050, EnergyPLAN software was chosen for the analysis of the scenarios in this study. EnergyPLAN is an system analysis tool which can be used for energy system analysis, feasibility studies and public regulation with respect to technological changes. The software was developed at Aalborg University in Denmark in collaboration with PlanEnergi and EMD A/S, and is distributed free of charge [23]. By using the analysis tool, models can be created and validated considering electricity, heat and transport as main sectors. In this study the EnergyPLAN 15.0 version was used. The EnergyPLAN tool requires extensive data. The main categories for inputs are: power plant capacities, production, distribution and demand. The outputs are energy distribution, fuel balance, $\mathrm{CO}_{2}$ emissions, electricity balance and energy specifications. The author of [24] gives a detailed overview of energy plan applications. The author states that EnergyPLAN was used in 95 peer reviewed articles by 2015; 76 of the articles were on the country or state level; 13 local; and six comprised more than one state or country. The topics or scope of these articles include integration of RES into energy system in 30 articles, RES scenarios in 21 articles and transport in 6 articles.

\subsection{Data Sources and Assumptions}

The modelling and analysis were based on regional and national data. The reference energy model was constructed and calibrated based on 2018 data. Energy production by region [25] and consumption by sector [26] were collected from Statistics Norway. Data regarding the status of hydroelectric power generation such as installed capacity, plant type, storage size, annual capacity and annual production were obtained from The Norwegian Water Resource and Energy Directorate (NVE) [27]. Wind power data were also collected from NVE [28]. Numbers of registered vehicles of different categories and annual mileage were obtained from Statistics Norway [29,30]. Data on heating systems and their characteristics were from the Norwegian District Heating Association [31] and Statistics Norway [32]. Additionally, an overview of the work process can be found in Figure 1. 


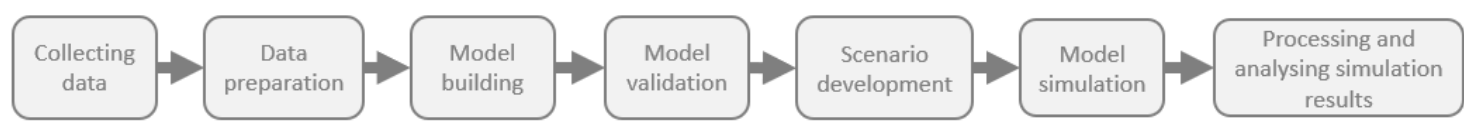

Figure 1. Work process block chart.

\section{Climate and Energy Strategy for Viken County}

Viken is one of the new counties in Norway following the regional reform that reduced the number from nineteen to eleven as of 1 January 2020. The county Viken is located in eastern Norway, as seen Figure 2, and is the most densely populated county with 1,241,165 inhabitants on an area of 24,595 $\mathrm{km}^{2}$ (1 January 2020) [33]. Population density varies largely within the county from 672 inhabitants per $\mathrm{km}^{2}$ at the highest point, to 1 inhabitant per $\mathrm{km}^{2}$ as the lowest point. About $87 \%$ of the inhabitants in Viken live in densely populated areas [34]; however, the distances between some of these areas are large. The diversity in landforms and elevation in the county gives great variations in weather and climate. There are warmer winters along the coast and in the south, in contrast to the northern parts of Viken which experience longer and colder winters [34,35].

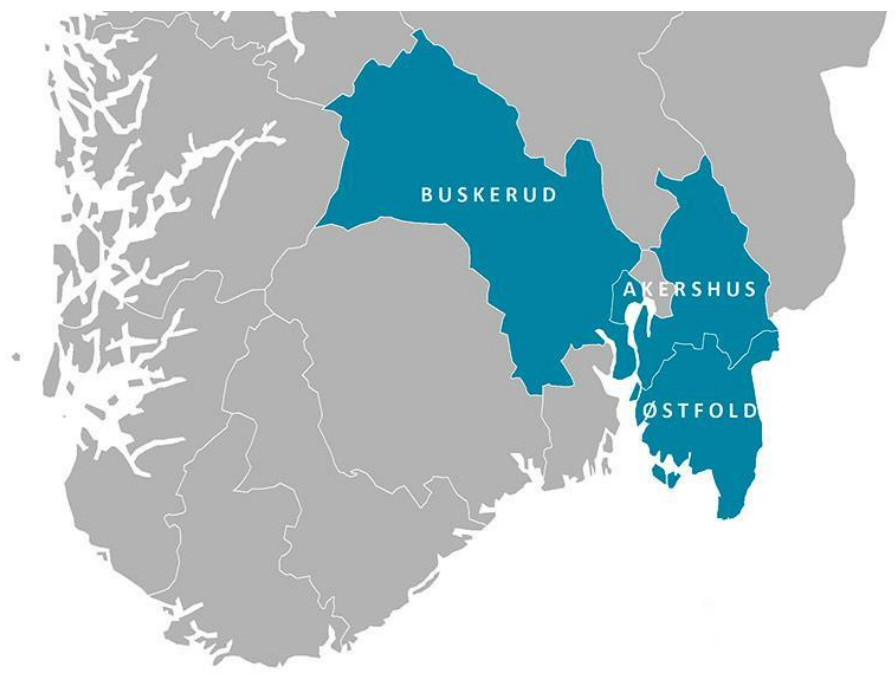

Figure 2. Location of Viken county [36].

Viken is a county wherein the transport sector has a more substantial impact on emissions compared to the rest of the country. Figure 3 shows the distribution of $\mathrm{CO}_{2}$ emissions for Viken and for Norway by sector. The data for Viken were $\mathrm{CO}_{2}$ eq corrected to illustrate $\mathrm{CO}_{2}$ emission [10,37]. The graph depicts that road transport has a significantly larger contribution to the emissions in Viken than in the rest of the country. In Norway as a whole, the manufacturing industry and oil and gas extraction have greater impacts on emissions than in Viken, whereas these sectors have small impacts in Viken. This again illustrates the importance of focusing on the road transport sector when analysing the energy system in the county of Viken.

The counties prior to the merging of Viken had different climate goals, but common goals for the new county are yet to be defined as of today. Two of the previous counties (Akershus and Buskerud) and Oslo have had a common regional climate policy since 1999. These policies mainly focus on increasing renewable energy, reducing emissions and reducing transport [13]. The regional goals defined by Akershus were chosen for this paper, and the relevant goals are presented in Table 1 . The main goals are: To reduce direct emissions with $55 \%$ by 2030 and have reduced the emission levels by $80-95 \%$ by 2050 compared to 1991 levels [38]. 


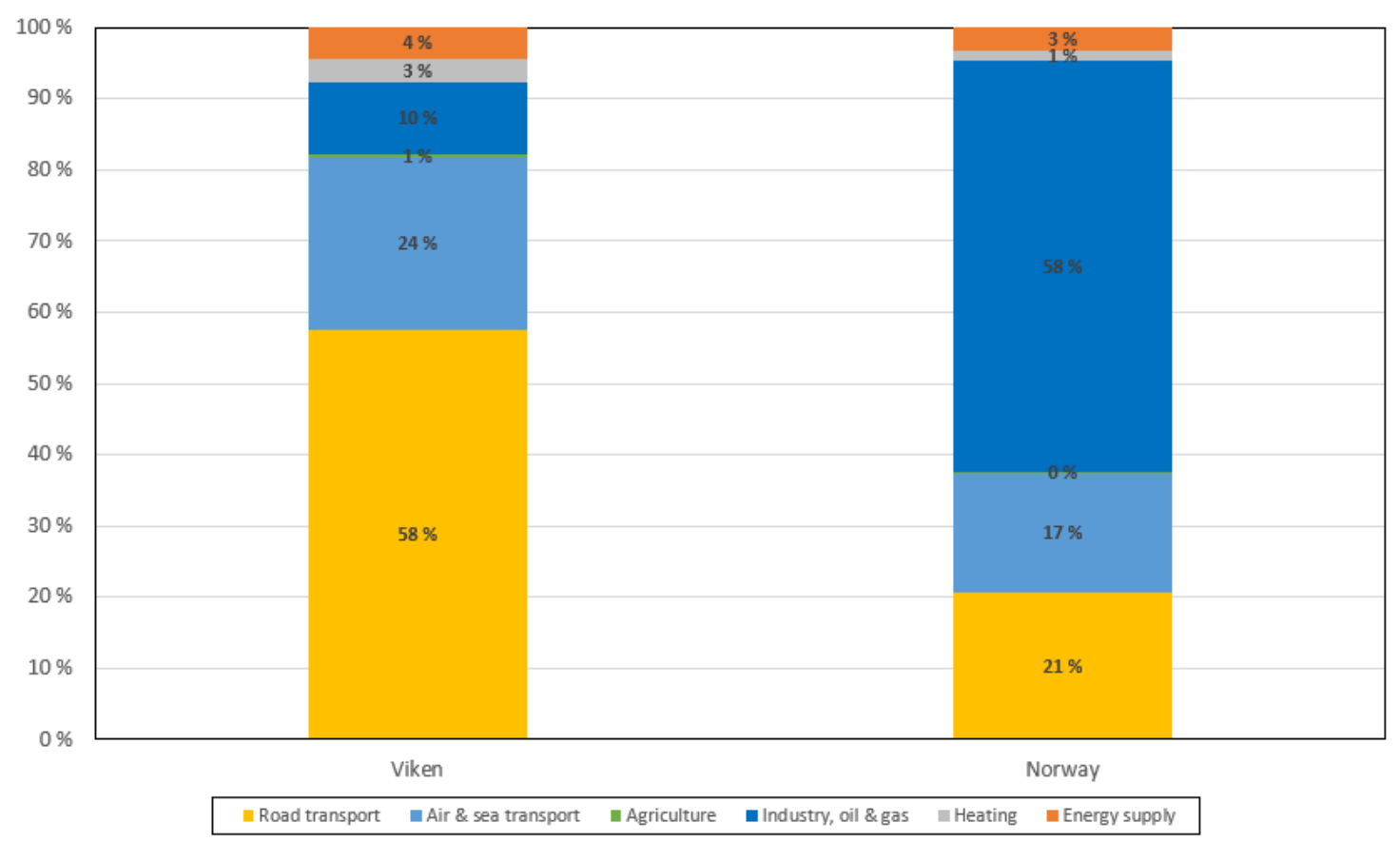

Figure 3. Distribution of $\mathrm{CO}_{2}$ emissions by sector in Viken and Norway 2018 [10,37,39].

Table 1. Regional climate and energy goals for 2030 and 2050 [38].

\begin{tabular}{ll}
\hline \multicolumn{1}{c}{ Description } \\
\hline By 2030 & \\
\hline & Emissions from transport sector reduced by at least $50 \%$ by 2030 compared to 1991 levels. \\
& All public transport renewable by 2020, and gradually transitioning to fossil free fuels. \\
& All new light vehicles zero-emission by 2025 \\
& At least $50 \%$ of all new heavy vehicles zero-emission by 2030 \\
& Increase amount of biogas in heavy vehicles by 2030 \\
& Infrastructure for fossil free transport established by 2025 \\
& Building and construction sites emission free or fossil free by 2030 \\
& Stop using fossil fuels for heating buildings and district heating by 2030 \\
\hline By 2050 & \\
\hline & All energy fossil free \\
& Emissions reduced by at least $80 \%$ compared to 1991 levels. \\
Increase renewable energy share & Climate neutrality
\end{tabular}

\section{Viken Energy System Characteristics}

The electricity consumption in the region around the capital has increased over the last few years. Statnett, the transmission system operator and owner of the national power grid has identified the causes to be increased population and an increase in the number of residential and office buildings. Statnett also identified five driving forces for increases in power consumption in the future: population growth, number of households, non-electric sources for heating, climate change and electrification of the national vehicle fleet. Statnett estimates that electric cars will be the largest contributor to the increased demand after 2030 [40]. Non-electric heating sources will have a net positive effect on the electrical grid. From January 2020 the use of oil and gas for heating purposes in private households was banned in Norway [41]. Many households have switched to more environmental friendly sources of energy to cover their heating demands. These can be solar collectors and heat pumps, yet bio-oil and biofuel are also options. 


\subsection{Electricity}

The electricity consumption within the county is higher than the generation, and the county relies on import of electric power [35]. The total electricity demand in Viken in 2018 was 19,596 GWh: private households (9352 GWh), secondary dwellings (502 GWh), primary industries (332 GWh), services (5691 GWh) and mining and manufacturing (4221 GWh) [26,42]. Electricity demand is higher during the winter months which is related to widespread use of electricity as the main heating source. Use of heat pumps (HP) for space heating has increased significantly for a number of years [43]. Between 1990 and 2006, households had a relatively stable demand between approximately 17,000 kWh in 1990 and 15,000 kWh in 2006 [44]. Furthermore, Statistics Norway states that an average household had a demand of 16,825 kWh in 2018 [45]. The electricity demands for heating differ between sources [46-48]. Therefore, the average value of the different sources was used. The amounts for space heating and water heating were set to $63 \%$ and $14 \%$ respectively; the remaining electricity is used for miscellaneous electrical appliances. However, it is important to recognise that heating demand varies throughout the year, due to climate variations [40].

Electricity generation in Viken is almost $100 \%$ renewable, as most of the generation comes from hydro power plants. There are currently a total of 138 hydroelectric power plants in operation with a total annual production of 15,146 GWh in 2018 and a total installed capacity of 3278 MW [27]. Power production from the hydroelectric power plants is more or less stable, even though this can vary annually. Though the contribution is small, there is also electricity production from thermal power plant corresponding to 51.24 GWh [49]. There is currently one wind power plant in Viken, located in Marker, in the south east of the county that was operating in 2019. The power plant consists of fifteen turbines with a total installed capacity of $540 \mathrm{MW}$ with an annual production of $192 \mathrm{GWh}$ [28]. When it comes to the use of solar energy in the region, there are challenges to finding data. It is generally known that the use of solar PVs is limited to residential, public and commercial buildings. The only data available for solar PVs are on the national level. According to [50], the total installed PV capacity in Norway was 23.5 Megawatt peak (MWp) in 2018. In total, around 20\% of all PV systems receiving government grants in the country are installed in Akershus. In addition, there are a number of systems not included in the Enova statistics due to lack of funding. PV systems are typically dimensioned to not exceed the demand, and excess production is usually fed to the electrical grid, as energy storage in battery banks is not common at this time. The power production of solar panels and solar collectors can be considered negligible.

\subsection{Heating}

The heating demands in the county are covered by direct electric heating, district heating and wood burning. District heating is available in most of the larger cities within the county. According to Statistics Norway [32], gross production of district heating in Norway was 6833 GWh in 2018. In Viken County there are 25 district heating plants with an annual production of $902 \mathrm{GWh}$ of heat [31]. The district heating plants in Viken are largely based on biomass and ambient heat sources, such as sea, sewage and solar collectors. There is one district heating plant in Viken utilising solar collectors as a heat source. In 2018 solar collectors supplied 4768 MWh of heat. Viken has also additional district cooling production of $100.36 \mathrm{GWh}[31,35]$.

In 2018, approximately 280,000 households used firewood as a heating source in Viken [35]. According to statistics Norway, approximately 197,000 tonnes of firewood was used in Viken in 2016 [51]. However, thanks to contact with the county forest ranger and Viken county, we were told that the wood heating demand was difficult to determine. Moreover, the sale of firewood has decreased proportionally with the increased sale of electric heat pumps. Therefore the estimate from Statistics Norway might contain inaccuracies. Furthermore, there are private biomass based heating plants for agricultural purposes in Viken. There is a total heating load of 185 GWh in 2017 [52]. However, it should be noted that it was said by the publisher of the data that there are inaccuracies due to heating units funded by Enova not being included in the data series. Heat supply from heat pumps 
was estimated using data provided by correspondence with Enova combined with statistics from The Co-operative Housing Federation of Norway (NBBL) [53] and Statistics Norway [54]. The number of installed HPs was calculated as 197,937 units. It should be noted that the estimated number of HPs is based on Enova grants and does not include HPs which did not receive funding from Enova. The total amount of heat supplied by HPs is estimated to 3.947 TWh and this corresponds to an electricity demand of 1.71 TWh with an assumed coefficient of performance (COP) of 2.3. The estimation was made by using data provided by NVE and Consumption Research Norway (SIFO) $[55,56]$.

\subsection{Transport}

The transport sector is responsible for most of the GHG emissions in Viken county [10]. In 2018 there were 833,265 vehicles (buses, vans, passenger cars and lorries) registered in the county; 2543 of these were buses, 688,573 were passenger cars, 124,241 were vans (under $3.5 \mathrm{t}$ ) and 17,908 were lorries (over $3.5 \mathrm{t}$ ). Tractors, motorbikes and snowmobiles are not considered in this paper. Of all passenger cars approximately 57,000 are electric [29]. Over 11,830 million kilometres were driven by vehicles registered to owners in Viken; of that, $78 \%$ was done by private cars, $17 \%$ by vans, $4 \%$ by lorries and approximately $1 \%$ by buses [30]. This distribution is depicted in Figure 4 . In 2018 the total driving distance for buses in public transport has been reported to approximately $129,500,000 \mathrm{~km}[57,58]$.

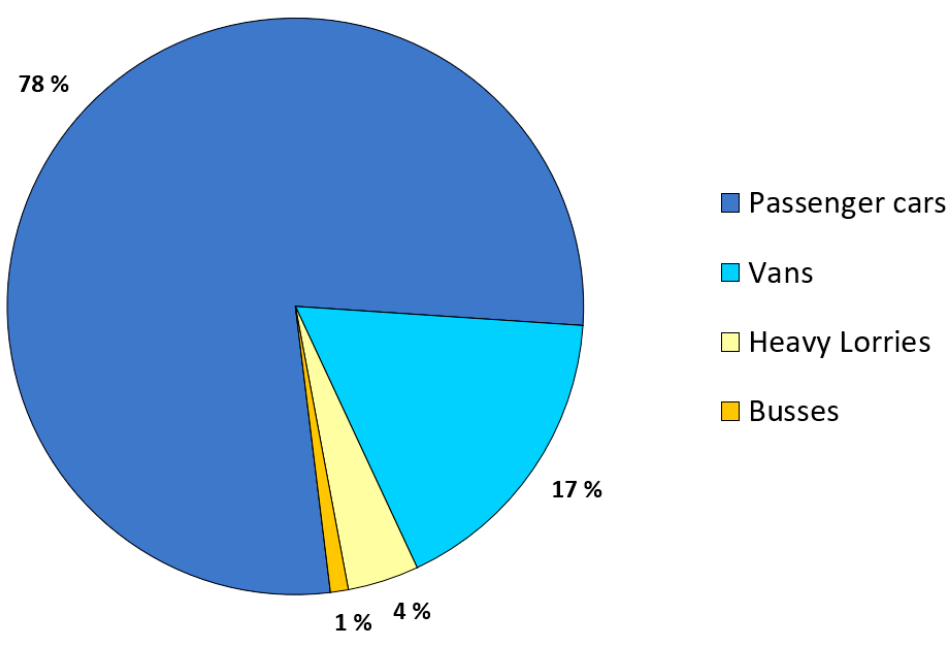

Figure 4. Percentage of total driving distance by vehicle type in 2018.

The national average age of private cars is 10.5 years, and the figure for Viken is 10.1 years (Østfold 11.1 years, Buskerud 10.2 years and Akershus 9.0 years) in 2018 [59]. There are 0.72 cars per person in Viken; this value is higher than the national average which is 0.66 [60-62]. This include both fossil fuelled and non-emission cars. In 2018 new car sales were $31.6 \%$ electric and at the end of 2019, the share was $42.36 \%$ [63]. In 2019, the combined counties that today represent Viken reached the milestone of $10 \%$ electric private cars, and a national average of 10\% electric private cars is estimated to be reached in 2020. Today the market share of new car sales is $47.9 \%$ electric in Viken and $50.5 \%$ nationally [63]. The high sales are due to incentives to aid the transition from conventional fossil vehicles to electric vehicles, such as tax exemptions and driving privileges, such as lowered rates on toll roads, zero value added tax (VAT) on purchase, access to public transport lanes and free or reduced parking fees $[11,64,65]$. The public transport companies in the region have also established goals to electrify their fleets of buses and ferries [40]. In 2019 approximately 10\% of buses for Ruter (Oslo \& Akershus) were electric, along with 39 buses in Akershus and 70 in Oslo. By 2028 all public transport is intended to be $100 \%$ electric to reach the zero-emission goal [66]. Brakar in Buskerud received its six first electric buses in 2019; by the end of 2020 additional 22 buses will be in operation. Their goal is to achieve a zero-emission fleet by 2030 [67]. Table 2 gives an overview of the vehicle fleet registered in 
Viken in 2018. One of the main motorways in the country goes through Norway from the Swedish border in Viken to Kirkenes in northern Norway. The motorway brings with it a lot of traffic from Europe. There were approximately 8.4 million vehicles traversing the border in 2018 . The breakdown of vehicles was $90.6 \%$ light vehicles and $9.4 \%$ heavy vehicles [68]. Data were gathered from multiple sources to produce an estimate of energy consumption and fuel consumption and are presented in Tables 2 and 3. Hybrid vehicles have varying driving patterns which makes it hard to define a mean fuel consumption of electricity and fossil fuels. In this paper it is assumed that hybrid vehicles run $50 \%$ on electricity and $50 \%$ on fossil fuels. Moreover, it is assumed that electric private cars have a fuel consumption of $20 \mathrm{kWh}$ per $100 \mathrm{~km}$ [69].

Table 2. Number of registered electric vehicles in the county, driving distance and electricity consumption in 2018 [29,30].

\begin{tabular}{llcccc}
\hline $\begin{array}{l}\text { Fuel } \\
\text { Type }\end{array}$ & $\begin{array}{l}\text { Vehicle } \\
\text { Type }\end{array}$ & $\begin{array}{c}\text { No. of Reg. } \\
\text { Vehicles }\end{array}$ & $\begin{array}{c}\text { Avg. Driving } \\
\text { Dist. } \mathbf{k m} / \mathbf{y r}\end{array}$ & $\begin{array}{c}\text { Elec. Energy } \\
\mathbf{k W h} / \mathbf{k m}\end{array}$ & $\begin{array}{c}\text { Tot. Elec. Energy } \\
\text { Consumption } \mathbf{k W h} / \mathbf{y r}\end{array}$ \\
\hline Electricity & & & & & \\
& Private cars & 56,970 & 13,753 & 0.2 & $156,701,682$ \\
& Vans & 1326 & 8393 & 0.25 & 331 \\
& Lorries & 1 & 42,037 & 1.2 & 50,444 \\
& buses & 14 & 46,372 & 1.2 & 649,208 \\
\hline
\end{tabular}

Table 3. Number of registered vehicles in the county, and average driving distance in 2018 [29,30].

\begin{tabular}{|c|c|c|c|}
\hline $\begin{array}{l}\text { Fuel } \\
\text { Type }\end{array}$ & $\begin{array}{l}\text { Vehicle } \\
\text { Type }\end{array}$ & $\begin{array}{l}\text { No. of Reg. } \\
\text { Vehicles }\end{array}$ & $\begin{array}{l}\text { Avg. Driving } \\
\text { Dist. km/yr }\end{array}$ \\
\hline \multicolumn{4}{|l|}{ Hydrogen } \\
\hline & Private cars & 79 & 1384 \\
\hline \multicolumn{4}{|l|}{ Gas } \\
\hline & Private cars & 66 & 6175 \\
\hline & Vans & 101 & 13,426 \\
\hline & Lorries & 80 & 18,976 \\
\hline & buses & 20 & 41,877 \\
\hline \multicolumn{4}{|l|}{ Petrol Hybrid } \\
\hline & Private cars & 65,050 & 14,350 \\
\hline & Vans & 38 & 12,415 \\
\hline \multicolumn{4}{|l|}{ Diesel Hybrid } \\
\hline & Private cars & 1174 & 18,678 \\
\hline \multicolumn{4}{|l|}{ Petrol } \\
\hline & Private cars & 277,082 & 9650 \\
\hline & Vans & 7176 & 8111 \\
\hline & Lorries & 773 & 338 \\
\hline & buses & 66 & 5096 \\
\hline \multicolumn{4}{|l|}{ Diesel } \\
\hline & Private cars & 288,134 & 15,353 \\
\hline & Vans & 115,598 & 15,826 \\
\hline & Lorries & 17,026 & 31,149 \\
\hline & buses & 2443 & 13,869 \\
\hline
\end{tabular}

Electric Vehicles' Impact on the Power Grid

The increasing number of electric cars is expected to have a significant role in the future, with power peaks due to EV chargers; however, the actual energy consumption will likely not be significant [70]. Large power peaks in the electrical distribution grid can create inadequate voltage quality, which can lead to failure, or in worst case scenarios, fires in electrical appliances [69]. Home charging of EVs results in peak activity around midnight; however, between the hours of 08:00 
and 18:00 there is little activity [71]. There are multiple options for charging with external control. The direct option would be immediate charging when connected to the grid, whilst another option would be delayed charging as one is connected to the grid to prevent peak loads and charging when the electricity price is lower. With the implementation of electric vehicles, there is the option of using the vehicles as energy storage units either connected to the grid (V2G) or alternatively to a building (V2B) to flatten the peak demand with direct supply [72]. In a study about the implementation of V2G in Nordic countries, there was a total of 61 interviews of politicians and academics in Norway, where 19 proposed V2G mechanisms, and 8 of the 19 stated that reconstructing the electricity market would promote V2G [73].

\section{Validation of Baseline for 2018}

The model has been calibrated with the data from the baseline 2018. The Norwegian Environment Agency has estimated that the total greenhouse gas emissions in Viken County are 4094 million tonnes. This includes the following sectors: industry, energy supply, heating, road traffic, sea transport, air transport, miscellaneous mobile combustion, agriculture and waste. The Norwegian Environment Agency estimates that the total emissions when restricted to road traffic, energy supply, industry and heating are 2.697 million tonnes, of which $72.6 \%$ come from the transport sector. However, it is important to note that The Norwegian Environment Agency only considers emissions from the transport within the boundaries of the county and has adopted $\mathrm{CO}_{2} e q$ [10]. For simplification reasons, this paper only considers the emissions from registered vehicles in $\mathrm{CO}_{2}$ levels, not $\mathrm{CO}_{2}$ eq. However, the $\mathrm{CO}_{2} e q$ and $\mathrm{CO}_{2}$ levels in transport vary little. Furthermore, there are differences in $\mathrm{CO}_{2}$ emissions presented in this paper, compared to the emissions presented by The Norwegian Environment Agency. The differences in emissions were considered to be reasonable, due to the definition of transport emissions from the Norwegian Environment Agency and the focus of the paper being potential in the transport sector. Once the model was verified it was possible to run alternate scenarios with changes corresponding to the aforementioned goals for 2030 and 2050. The reference model for 2018 has been verified by comparing the model output data with the source data.

\section{Energy System Scenarios for 2030 and 2050}

The framework for the design of the scenarios is based on the goals for development of renewable energy sources and emission reduction in Viken for 2030 and 2050. The scenarios for 2030 and 2050 were constructed after dialogue with Viken county where the representatives for the county shared future plans including energy supply and demand potential. Furthermore, the models for 2030 and 2050 are based on Viken's goals for public transport being zero-emissions combined with the distribution of fuel consumption for 2030 and 2050 based on a projection of private cars and lorries by the Institute of Transport Economics (TØI) [74]. Even though this paper focuses on electric vehicles, there are alternative low-emission fuels that also can be considered, such as biogas and biodiesel; however, these are limited resources, which makes it difficult to justify them from a sustainability standpoint. Battery electric vehicles were chosen based on the historical trend in Norway due to incentives and the projected future vehicle fleet from The Institute of Transport Economics [64,74]. Furthermore, the increasing share of RES in the power production mix advocates for expanded use of electric vehicles. Regarding the size of the vehicle fleet in the models for 2030 and 2050, it is adjusted by considering the population in Viken will increase to 1.336 million in 2030 and 1.469 million in 2050 [75]. The breakdown of fuel use for transport for each scenario is given in Table 4 for 2030 and in Table 5 for 2050. The scenarios in this paper focus mainly on the transport sector and to some extent the integration of renewable energy. Supply and demand of heat are assumed to be constant in both 2030 and 2050. This is also supported by the number of buildings and households, which are important driving factors for the electricity consumption in the county. The electricity demand will, however, not increase significantly due to increased demolition of old buildings and construction of low-energy and 
zero-emission buildings (ZEB) with lower heating demands [40]. Furthermore ZEB would be crucial to achieve a GHG reduction in the construction sector [76].

Table 4. Vehicle and fuel distribution in scenario 2030.

\begin{tabular}{lccc}
\hline & Cars and Vans & Buses & Lorries \\
\hline Petrol & $8 \%$ & $0 \%$ & $1 \%$ \\
Diesel & $23 \%$ & $0 \%$ & $73 \%$ \\
Electric & $56 \%$ & $68 \%$ & $0 \%$ \\
Hybrid & $8 \%$ & $0 \%$ & $15 \%$ \\
Hydrogen & $5 \%$ & $32 \%$ & $11 \%$ \\
\hline
\end{tabular}

\subsection{Scenario 2030}

- Electricity production from wind of $0.19 \mathrm{TWh}$ is added from the wind power plant in Marker which was commissioned in 2019.

- The electricity demand increases by 1.53 TWh compared to baseline due to switching from fossil fuels to electricity in transport.

- Commercial electricity production from solar PV increased to $1 \mathrm{TWh}$.

- Production from hydroelectric power plants will be kept constant.

- Heating demand remains the same as in the baseline scenario.

- The total number of vehicles increases from 812,551 to 884,385 .

- New breakdown of fuel use as shown in Table 4.

- Private solar energy has not been included.

\subsection{Scenario 2050}

- Wind energy production increases from 0.19 TWh to 1.0 TWh.

- Electricity production from solar PV remains the same as 2030.

- Heating demand unchanged from baseline scenario.

- The electricity demand further increases by 2.09 TWh compared to the baseline.

- $\quad$ The total number of vehicles increases from 884,385 to 972,497 .

- $\quad$ New breakdown of fuel use as shown in Table 5.

- Private solar energy has not been included.

Table 5. Vehicle and fuel distribution in scenario 2050.

\begin{tabular}{lccc}
\hline & Cars and Vans & Buses & Lorries \\
\hline Petrol & $0 \%$ & $0 \%$ & $0 \%$ \\
Diesel & $1 \%$ & $0 \%$ & $13 \%$ \\
Electric & $86 \%$ & $45 \%$ & $0 \%$ \\
Hybrid & $0 \%$ & $0 \%$ & $19 \%$ \\
Hydrogen & $13 \%$ & $55 \%$ & $68 \%$ \\
\hline
\end{tabular}

\section{Results}

This section presents simulation results for the different scenarios. The results are based on data from Section 4. The results from the simulation of the different scenarios focus primary on energy supply, renewable energy share and emission.

\subsection{Energy Distribution}

Figure 5 gives an overview of the energy balance in Viken for the simulated scenarios. As can be seen from the figure, the renewable energy share of the PES increases significantly from $68 \%$ in 2018 to $83 \%$ in 2030 and to $92 \%$ in 2050 . When it comes to power generation, hydro power plays a major role with an annual generation of 15.14 TWh in Viken in all scenarios. The contribution from wind 
power is 0.19 TWh in 2030 and this will increase to 1 TWh in 2050. Solar PV is 0 in 2018 and produces 1 TWh in both 2030 and 2050. Regarding the use of fossil fuels, there is a significant reduction from 8.54 TWh in 2018 to 3.93 TWh in 2030 and 1.74 TWh in 2050. Electrification within the transport sector is the main factor in reducing the use of fossil fuels-in this case oil. Therefore, the use of oil decreases from 6.8 TWh in 2018 to 2.3 TWh in 2030 and 0.1 TWh in 2050. It should be noted here that uses of coal and natural gas have fixed values for all scenarios- -0.14 and 0.68 TWh respectively. The same is true for biomass with an annual use of 2.51 TWh in all scenarios. As indicated previously, Viken relies on the importation of power to meet its demands. Imported electricity changes from $6.89 \mathrm{TWh}$ in 2018 to 7.12 TWh in 2030 and 7.15 TWh in 2050. Although Viken has to import electricity outside the system's boundaries, there are periods where the system exports power. The amount of exported power is more or less the same in all scenarios, ranging between 2.64 and $2.82 \mathrm{TWh}$.

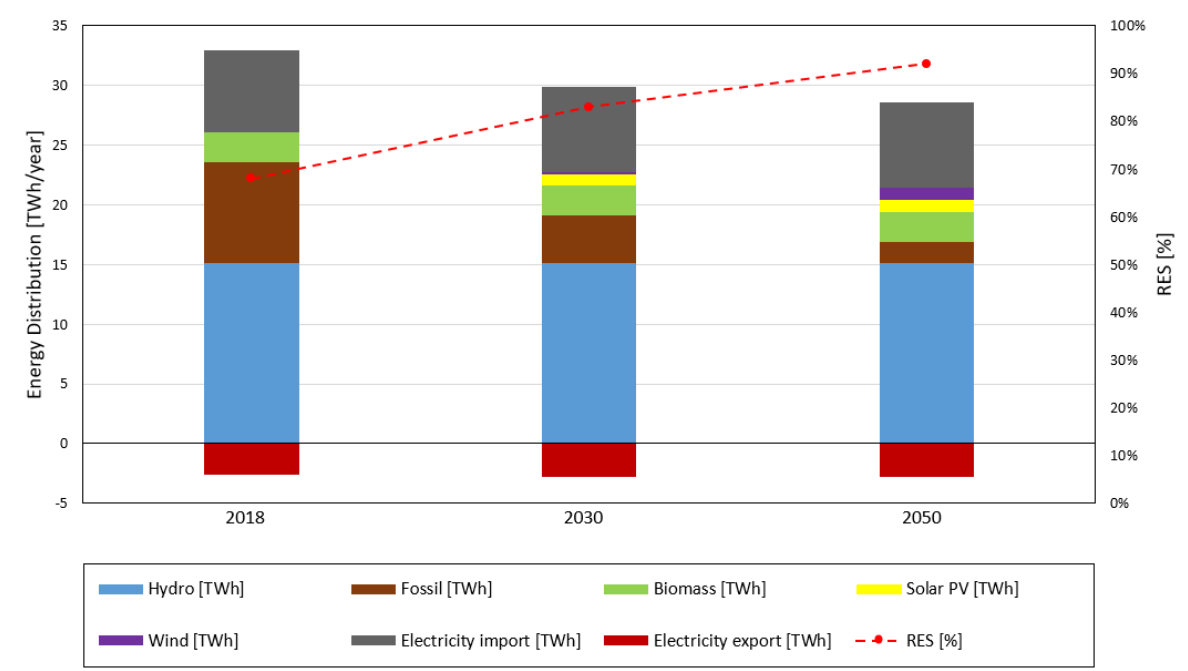

Figure 5. Energy distribution.

\section{2. $\mathrm{CO}_{2}$ Emissions}

$\mathrm{CO}_{2}$ contributions from the different sectors for the different scenarios are presented in Figure 6. As can be seen from the figure, the road traffic with its share of $47 \%$ accounts for main part of the county's total emissions in the baseline scenario. The electrification of the transport sector contributes to substantial reduction of $\mathrm{CO}_{2}$ emissions in 2030 and 2050. Thus the emission levels in road transport in 2030 are reduced by $66 \%$, and emission levels in 2050 are reduced by $98.35 \%$ with respect to the reference year 2018. The overall total $\mathrm{CO}_{2}$ emissions reduction with respect to 2018 for 2030 is $31.0 \%$, and it is $46.01 \%$ for 2050 if no other emission-reducing measures are taken in the other sectors. 


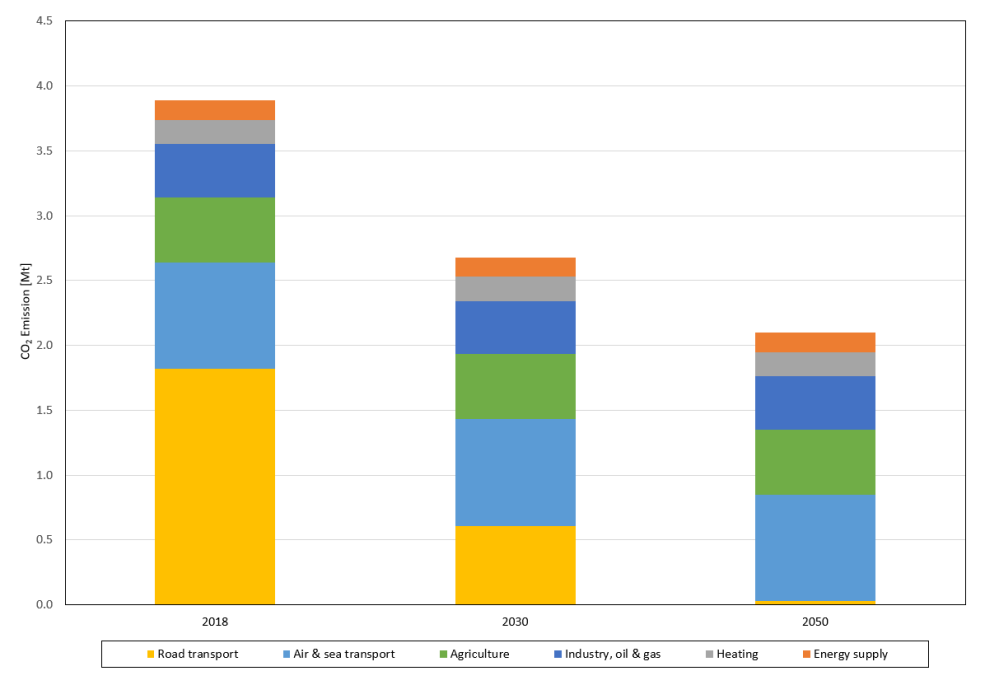

Figure 6. $\mathrm{CO}_{2}$ emissions (Mt).

\section{Discussion}

In this paper, a comprehensive energy system model of Viken county was developed by using the energy system analysis tool EnergyPLAN. The prospects of switching to environmentally friendly transport and integration of renewable energy, in this case, solar and wind energy, were studied. Hydro power plays a major role within the county, accounting for a substantial share of the supply in all scenarios. Fossil fuels have the next largest share in the baseline scenario, but this will decrease significantly in 2030 and 2050 as a result of electrification in the transport sector. Viken's climate goals regarding reduction in emission levels can be read in Section 3. However, the ambitious goals depends upon a multiplex of factors. Thus some of Viken's goals are considered to be largely outside of the county's influence. The sale of zero-emission vehicles is dependant on technological advancements and national policies, which is why Viken's goals regarding private transport have not been included. Norway's incentives for electric vehicles have lead to the high share of electric cars in the flow of new vehicles into the country and the relatively high share of electric cars nationally at $10 \%$. However, each county in Norway is responsible for public transport; therefore, goals regarding public transport were included in the scenarios. Viken's intention of increasing renewable energy sources has been included; the modelled scenarios resulted in increased renewable energy shares of $15 \%$ in 2030 and $24 \%$ in 2050 with respect to 2018 due to added wind and solar power production.

It should be noted here that no measures that promote the reduction of emissions in the industry sector have been considered in this study. In a conversation with a Viken county representative, it was stated that energy consumption in industry was regarded as sensitive data; because of that the available data that were used for the models were outdated. As mentioned in Section 7.1, reduced use of fossil energy depends on electrification of the transport sector. The electrification of the transport sector will imply reduced use of oil by $98.5 \%$ in 2050 with respect to 2018 . The implementation of a zero-emission transport sector in the model leads to a total reduction of $31 \%$ in 2030 and $46 \%$ in 2050 with respect to 2018, with the emission levels from transport alone being reduced by $66 \%$ in 2030 and $98.5 \%$ in 2050 . The results state that attaining a zero-emission vehicle fleet as defined in scenario 2030 and 2050 alone is not sufficient to reach the county's aforementioned goals with regards to transport. If the described scenarios are achieved, an increased demand will follow with larger power peaks in the electrical grid than the present. The implementation of V2G and V2B can help flatten power peaks induced by EVs and hydrogen fuel production, yet implementing new technology will call for a renovated power grid which can lead to large expenses. 


\section{Conclusions}

The increasing awareness of climate issues and environmental policy has been a key factor behind the continuous transition of energy systems at different levels. Substantial changes in the transport sector are required to produce the results presented in this paper. The proposed scenarios give a partial overview of a larger picture. The requirements for implementing the scenario for 2030 and 2050 are feasible if there are adequate political decisiveness, legislative action, technological advancements to improve upon the quality of the electric grid, technological advancements of zero-emission vehicles and increases charging infrastructure. Our results and conclusion will only be accurate under the conditions that were assumed in the models created for this paper.

\section{Future Work}

The future work arising from this study should include all sectors in the county to further improve the accuracy of model. More investigation should be done into the implications on the power grid caused by the increased electricity consumption due to electrification of the transport sector and also the integration of intermittent energy sources. Furthermore, an analysis of the costs associated with this transition and sustainable assessment is needed.

Author Contributions: Conceptualisation, F.E.A. and S.G.R.; methodology, F.E.A. and S.G.R.; software, S.G.R.; validation, F.E.A. and S.G.R.; formal analysis, F.E.A. and S.G.R.; data curation, F.E.A. and S.G.R.; writing-original draft preparation, F.E.A., S.G.R. and A.G.; writing-review and editing, F.E.A., S.G.R. and A.G.; visualisation, F.E.A. and S.G.R.; supervision, A.G. All authors have read and agreed to the published version of the manuscript.

Funding: The APC was funded by NTNU - Norwegian University of Science and Technology.

Acknowledgments: We would like to acknowledge Viken county for valuable insights and data. The authors are very grateful to the three anonymous reviewers for their constructive comments and suggestions proposed to improve on the quality of this paper.

Conflicts of Interest: The authors declare no conflict of interest.

\section{References}

1. United Nations Framework Convention on Climate Change. The Paris Agreement. Available online: https: / / unfccc.int/process-and-meetings/the-paris-agreement/the-paris-agreement (accessed on 14 May 2020).

2. European Commission. 2030 Climate \& Energy Framework. Available online: https://ec.europa.eu/clima/ policies/strategies/2030_en (accessed on 22 May 2020).

3. European Commission. A European Green Deal. Available online: https://ec.europa.eu/info/strategy/ priorities-2019-2024/european-green-deal_en (accessed on 22 May 2020).

4. European Commission. European Climate Law. Available online: https://ec.europa.eu/clima/policies/euclimate-action/law_en (accessed on 22 May 2020).

5. United Nations Framework Convention on Climate Change. Update of Norway's Nationally Determined Contribution. Available online: https://www4.unfccc.int/sites/ndcstaging/PublishedDocuments/ Norway\%20First/Norway_updatedNDC_2020\%20(Updated\%20submission).pdf (accessed on 11 May 2020).

6. Ministry of Climate and Environment. Norway Steps up 2030 Climate Goal to at Least 50\% towards 55\%. Available online: https:/ / www.regjeringen.no/en/aktuelt/norge-forsterker-klimamalet-for-2030-til-minst50-prosent-og-opp-mot-55-prosent/id2689679/ (accessed on 11 May 2020).

7. Office of the Prime Minister. Granavolden-Plattformen, 2019. Available online: https://www.regjeringen. no/no/dokumenter/politisk-plattform/id2626036/ (accessed on 1 September 2020).

8. Statistics Norway. Production and Consumption of Energy, Energy Balance, 2019. Available online: https:/ / www.ssb.no/en/energi-og-industri/statistikker/energibalanse (accessed on 2 June 2020).

9. The Norwegian Energy Regulatory Authority. Electricity Disclosure 2018. Available online: https://www. nve.no/norwegian-energy-regulatory-authority/retail-market/electricity-disclosure-2018/ (accessed on 10 May 2020).

10. Norwegian Environment Agency. Utslipp av Klimagasser i Kommuner. Available online: https://www. miljodirektoratet.no/tjenester/klimagassutslipp-kommuner?area=1046 (accessed on 17 February 2020). 
11. Ministry of Transport. Norway Is Electric, 2019. Available online: https://www.regjeringen.no/en/topics/ transport-and-communications/veg/faktaartikler-vei-og-ts/norway-is-electric/id2677481/ (accessed on 6 June 2020).

12. International Energy Agency. Norway Key Energy Statistics, 2018. Available online: https://www.iea.org/ countries/norway (accessed on 12 May 2020).

13. Hvoslef, S.; Christensen, T.; Greatorex, J.; Grundt, G. Klimahandlingsplan 2030 for Osloregionen, 2009. Available online: http:/ / www.bfk.no/Documents/BFK/Regionalutvikling/Regionale\%20planer\%20og\% 20strategier/Klimahandlingsplan\%202030\%20for\%20Osloregionen.pdf (accessed on 25 May 2020).

14. Lund, H.; Mathiesen, B.V. Energy system analysis of $100 \%$ renewable energy systems-The case of Denmark in years 2030 and 2050. Energy 2009, 34, 524-531. [CrossRef]

15. Fischer, R.; Elfgren, E.; Toffolo, A. Towards Optimal Sustainable Energy Systems in Nordic Municipalities. Energies 2020, 13, 290. [CrossRef]

16. Ibrahimi, N.; Gebremedhin, A.; Sahiti, A. Achieving a Flexible and Sustainable Energy System: The Case of Kosovo. Energies 2019, 12, 4753. [CrossRef]

17. Ćosić, B.; Krajačić, G.; Duić, N. A 100\% renewable energy system in the year 2050: The case of Macedonia. Energy 2012, 48, 80-87. [CrossRef]

18. Child, M.; Ilonen, R.; Vavilov, M.; Kolehmainen, M.; Breyer, C. Scenarios for sustainable energy in Scotland. Wind Energy 2019, 22, 666-684. [CrossRef]

19. Burandt, T.; Xiong, B.; Löffler, K.; Oei, P.Y. Decarbonizing China's energy system-Modeling the transformation of the electricity, transportation, heat, and industrial sectors. Appl. Energy 2019, 255, 113820. [CrossRef]

20. Liu, L.; Zhu, T.; Pan, Y.; Wang, H. Multiple energy complementation based on distributed energy systems-Case study of Chongming county, China. Appl. Energy 2017, 192, 329-336. [CrossRef]

21. Lund, H.; Münster, E. Integrated transportation and energy sector $\mathrm{CO}_{2}$ emission control strategies. Transp. Policy 2006, 13, 426-433. [CrossRef]

22. Lund, H.; Kempton, W. Integration of renewable energy into the transport and electricity sectors through V2G. Energy Policy 2008, 36, 3578-3587. [CrossRef]

23. Department of Development and Planning, Aalborg University. EnergyPLAN. Available online: https:/ / www.energyplan.eu/ (accessed on 7 January 2020).

24. Østergaard, P.A. Reviewing EnergyPLAN simulations and performance indicator applications in EnergyPLAN simulations. Appl. Energy 2015, 154, 921-933. [CrossRef]

25. Statistics Norway. 08308: Produksjon av Elektrisk Kraft, Etter Art (GWh) (F) 2006-2018. Available online: https:/ / www.ssb.no/statbank/table/08308 (accessed on 13 January 2020).

26. Statistics Norway. 08312: Net Consumption of Electricity, by Consumer Group (GWh) (C) 2008-2018. Available online: https:/ /www.ssb.no/en/statbank/table/08312 (accessed on 13 January 2020).

27. The Norwegian Water Resources and Energy Directorate. Vannkraftdatabase, 2020. Available online: https: //www.nve.no/energiforsyning/kraftproduksjon/vannkraft/vannkraftdatabase/ (accessed on 5 May 2020).

28. The Norwegian Water Resources and Energy Directorate. Marker Vindkraftverk. Available online: www.nve.no/energiforsyning/vindkraft/utbygde-vindkraftverk/vindkraftverk/?id=10101 (accessed on 23 January 2020).

29. Statistics Norway. 11823: Registered Vehicles, by Euro Classes and Type of Fuel (M) 2016-2018. Available online: https:/ / www.ssb.no/en/statbank/table/11823 (accessed on 22 January 2020).

30. Statistics Norway. 12576: Road Traffic Volumes, by Home County of Vehicle Owner, Main Type of Vehicle and Type of Fuel (C) 2005-2018. Available online: https:/ /www.ssb.no/en/statbank/table/12576 (accessed on 22 January 2020).

31. District heating Norway. Fjernvarme-Energikilder 2018. Available online: https://www.fjernkontrollen.no/ (accessed on 5 February 2020).

32. Statistics Norway. 04727: Balance of District Heating (GWh) 1983-2018. Available online: https:/ / www.ssb. no/en/statbank/table/04727/ (accessed on 30 March 2020).

33. Viken Fylkeskommune. Fakta og Tall om Viken. Available online: https://viken.no/tjenester/planlegging/ analyse-statistikk-og-kart/fakta-om-viken/fakta-og-tall-om-viken/ (accessed on 1 September 2020).

34. Mæhlum, L. Viken in Store Norske Leksikon. Available online: https://snl.no/Viken (accessed on 7 February 2020). 
35. Viken Fylkeskommune. Vi i Viken - Kunnskapsgrunnlag for en Bærekraftig Framtid, 2019. Available online: https:/ / viken.no/_f/p1/i4f0b8206-d207-4524-b400-9200b65ae0f9/kunnskapsgrunnlag-regionalplanstrategi-viken-vi-i-viken.pdf (accessed on 7 January 2020).

36. Viken Fylkeskommune. Status Vedrørende Fremdrift i Viken Organisering. Available online: https: / / www.viken2020.no/for-ansatte/nyheter-for-ansatte/status-vedrorende-fremdrift-i-vikenorganisering.101344.aspx (accessed on 7 February 2020).

37. Statistics Norway. 08940: Greenhouse Gases, by Source (Activity), Energy Product, Contents and Year, 2020. Available online: https:/ /www.ssb.no/en/statbank/table/08940/ (accessed on 8 September 2020).

38. Akershus Fylkeskommune. Regional Plan for Klima og Energi i Akershus, 2018. Available online: https: / / www.akershus.no/file/0f840a80a6f03ac01ef1c6e9b5f6a295/Regional+plan+for+klima+og+ energi+i+Akershus+2018-2050+-+Vedtatt+18.06.2018.pdf (accessed on 1 April 2020).

39. Statistics Norway. Emissions to Air, 2020. Available online: https://www.ssb.no/en/natur-og-miljo/ statistikker/klimagassn (accessed on 19 September 2020).

40. Statnett, S.F. Forbruksprognose Stor-Oslo 2018, 2018. Available online: https://www.statnett. no/globalassets / for-aktorer-i-kraftsystemet/planer-og-analyser/2018-Forbruksprognose-Stor-Oslo (accessed on 17 February 2020).

41. Forskrift om Forbud mot Bruk av Mineralolje til Oppvarming av Bygninger, 2018. Ministry of Climate and Environment. Available online: https:/ / lovdata.no/dokument/SF/forskrift/2018-06-28-1060 (accessed on 2 June 2020).

42. Statistics Norway. 10314: Nettoforbruk av Elektrisk Kraft, Etter for Rukergruppe (GWh) (K) 2010-2018. Available online: https:/ / www.ssb.no/statbank/table/10314/ (accessed on 22 January 2020).

43. Halvorsen, B.; Larsen, B.M. Hvem eier varmepumpe og hva gjør det med strømforbruket? Økonomiske Anal. 2013, 2, 2013.

44. Dalen, H.M.; Larsen, B.M. Residential end-use electricity demand: development over time. Energy J. 2015, 36. [CrossRef]

45. Statistics Norway. 11563: Energiforbruk i Husholdninger og Fritidshus 1990-2018. 2018. Available online: https: / /www.ssb.no/statbank/table/11563/ (accessed on 17 February 2020).

46. Ministry of Finance. Energibruk i Husholdningene. Available online: https://www.regjeringen.no/no/ dokumenter/nou-2004-8/id385856/?ch=5 (accessed on 17 February 2020).

47. Bergesen, B.; Groth, L.H.; Langseth, B.; Magnussen, I.H.; Spilde, D.; Toutain, J.E.W. Energibruksrapporten 2012_Energibruk i Husholdninger. Oslo Nor. Water Resour. Energy Dir. 2012, 30, 2012.

48. Feilber, N.; Grinden, B. Ny Kunnskap om Fordeling av Strømforbruket. Available online: https: / www.sintef.no/globalassets/upload/energi/nyhetsbrev/ny-kunnskap-om-fordeling-avstromforbruket.pdf (accessed on 17 February 2020).

49. The Norwegian Water Resource and Energy Directorate. Termisk Kraft. Available online: https://www.nve. no/energiforsyning/termisk-kraft (accessed on 14 January 2020).

50. Norsk Solenergiforening. Solceller, 2019. Available online: https://www.solenergi.no/solstrm (accessed on 25 August 2020).

51. Aastad, K. Mindre ved Brennes i Gamle Ovner, 2018. Available online: https://www.ssb.no/natur-ogmiljo/artikler-og-publikasjoner/mindre-ved-brennes-i-gamle-ovner (accessed on 20 June 2020).

52. Norske Biovarneanlegg. Biovarme Norge, N/A. Available online: http://norskebioenergianlegg.no/ (accessed on 15 June 2020).

53. Amundsen, K.H. Energisystemer i Boligmassen - Beboeres Kunnskap, Holdninger og Tiltak for Energieffektivisering; Oslo, The Co-operative Housing Federation of Norway: Oslo, Norway, 2011.

54. Statistics Norway. 06265: Boliger, Etter Region, Bygningstype, Statistikkvariabel og år, 2018. Available online: https:/ / www.ssb.no/statbank/table/06265/tableViewLayout1/ (accessed on 20 February 2020).

55. Ericson, T.; Fidje, A.; Fonneløp, J.; Langseth, B.; Magnussen, I.; Rode, W.; Saugen, B. Varmepumper $i$ Energisystemet - Status og Muligheter; Oslo, The Norwegian Water Resources and Energy Directorate: Oslo, Norway, 2016.

56. Strandbakken, P.; Heidenstrøm, N.; Vittersø, G. Energisparende Teknologier i Norske Husholdninger; Oslo, Consumption Research Norway: Oslo, Norway, 2015.

57. Kollektivtrafikkforeningen. Markedsoversikten V18, 2018. Available online: https://kollektivtrafikk.no/ wp-content/uploads/2018/10/180610-MARKEDSOVERSIKT1.pdf (accessed on 5 August 2020). 
58. Kollektivtrafikkforeningen. Markedsoversikten V19, 2019. Available online: https:/ / kollektivtrafikk.no/ markedsoversikten-v19/ (accessed on 5 August 2020).

59. Statistics Norway. 05528: Average Age of Private Car or Van, by Region, Contents and Year, 2020. Available online: https:/ / www.ssb.no/en/statbank/table/05528/tableViewLayout1/ (acsessed on 9 June 2020).

60. Statistics Norway. 07832: Registered Vehicles, by Type of Vehicle and Trade Mark (M) 2008-2019, 2020. Available online: https: / www.ssb.no/en/statbank/table/07832/ (accessed on 8 June 2020).

61. Statistics Norway. 07459: Population, by Sex and One-Year Age Groups (M) 1986-2020, 2018. Available online: https: / /www.ssb.no/en/statbank/table/07459 (accessed on 8 June 2020).

62. Viken Fylkeskommune. Datasett: Folketall Etter Alder og Kjønn, 2019. Available online: https://statistikk. akershus-fk.no/webview/ (accessed on 8 June 2020).

63. Norwegian EV Association. Statistikk Med Salg av Elbiler i Norge, 2020. Available online: https:/ / elbil.no/ elbilstatistikk/elbilsalg/ (accessed on 25 August 2020).

64. Mersky, A.C.; Sprei, F.; Samaras, C.; Qian, Z.S. Effectiveness of incentives on electric vehicle adoption in Norway. Transp. Res. Part Transp. Environ. 2016, 46, 56-68. [CrossRef]

65. Figenbaum, E. Electromobility Status in Norway: Mastering Long Distances-The Last Hurdle to Mass Adoption; TØI Report 1627/2018; Oslo Institute of Transport Economics: Oslo, Norway, 2018.

66. Ruter. Slik Jobber vi Med Bærekraft, 2020. Available online: https://barekraft.ruter.no/ (accessed on 9 June 2020).

67. Brakar. Årsrapport 2019, 2020. Available online: http://arsrapport.brakar.no/ (accessed on June 92020 ).

68. The Norwegian Public Roads Administration. 8,4 Millioner over Svinesundsforbindelsen, 2019. Available online: https:/ / www.vegvesen.no/om+statens+vegvesen/presse/Pressemeldingsarkiv / Vegdirektoratet/8-4-millioner-over-svinesundsforbindelsen (accessed on 7 June 2020).

69. Skotland, C.H.; Eggum, E.; Spilde, D. Hva Betyr Elbiler for Strømnettet? Rapport nr 74-2016; Oslo The Norwegian Water Resources and Energy Directorate: Oslo, Norway, 2016.

70. Statnett, SF. Energi og effektprognoser for Oslo og Akershus mot 2050, $2011 . \quad$ Available online: https://www.statnett.no/globalassets/her-er-vare-prosjekter/region-ost/nettplan-stor-oslo/ energi-og-effektprognoser-for-oslo-og-akershus-mot-2050-delrapport-til-nettplan-stor-oslo.pdf (accessed on 25 August 2020).

71. Spilde, D.; Skotland, C. Hvordan vil en omfattende elektrifisering av transportsektoren påvirke kraftsystemet?; The Norwegian Water Resources and Energy Directorate: Oslo, Norway, 2015.

72. Richardson, D.B. Electric vehicles and the electric grid: A review of modeling approaches, Impacts, and renewable energy integration. Renew. Sustain. Energy Rev. 2013, 19, 247-254. [CrossRef]

73. Kester, J.; Noel, L.; de Rubens, G.Z.; Sovacool, B.K. Promoting Vehicle to Grid (V2G) in the Nordic region: Expert advice on policy mechanisms for accelerated diffusion. Energy Policy 2018, 116, 422-432. [CrossRef]

74. Fridstrøm, L.; Østli, V. Kjøretøyparkens Utvikling og Klimagassutslipp; TØI rapport 1518/2016; Oslo The Institute of Transport Economics: Oslo, Norway, 2016.

75. Statistics Norway. 12882: Population Projections 1 January, by Sex and Age, in 9 Alternatives (M) 2020-2050, 2020. Available online: https://www.ssb.no/en/statbank/table/12882 (accessed on 7 June 2020).

76. Hestnes, A.G.; Eik-Nes, N.L. Zero Emission Buildings; Fagbokforlaget: Bergen, Norway, 2017.

Publisher's Note: MDPI stays neutral with regard to jurisdictional claims in published maps and institutional affiliations.

(C) 2020 by the authors. Licensee MDPI, Basel, Switzerland. This article is an open access article distributed under the terms and conditions of the Creative Commons Attribution (CC BY) license (http:/ / creativecommons.org/licenses/by/4.0/). 